\title{
Identitas Yesus Sebagai Anak Allah Menurut Lukas 3:21-22
}

\author{
Liberatus Mayabubun ${ }^{\text {a, } 1}$ Johanis Luturmas ${ }^{\text {b,2 }}$

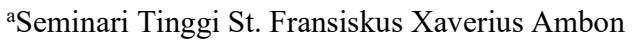 \\ ${ }^{\mathrm{b}}$ Sekolah Tinggi Pendidikan Agama Katolik Ambon \\ 1atustawurutubun@gmail.com \\ 2johnlutur@gmail.com
}

\begin{tabular}{|c|c|}
\hline \multicolumn{2}{|c|}{ Article History: } \\
\hline \multicolumn{2}{|c|}{ Submitted: 24 March 2021} \\
\hline Revised: & 8 July 2021 \\
\hline Accepted: & 24 Januari 2022 \\
\hline Keywords: & $\begin{array}{l}\text { Son of God; } \\
\text { Identity of Jesus; } \\
\text { Promulgation; } \\
\text { Baptism; Divine } \\
\text { Relationship }\end{array}$ \\
\hline \multicolumn{2}{|c|}{$\begin{array}{c}\text { Kata-kata Kunci: Allah Allah; } \\
\text { Identitas Yesus; } \\
\text { Promulgasi; } \\
\text { Pembaptisan; } \\
\text { Relasi Ilahi }\end{array}$} \\
\hline \multicolumn{2}{|c|}{$\begin{array}{l}\text { DOI: } \\
\text { https://doi.org/10.53396/media. } \\
\text { v3i1.28 }\end{array}$} \\
\hline
\end{tabular}

Copyright $($ C 2022, Author

\begin{abstract}
:
This essay discusses the identity of Jesus as the Son of God according to Luke 3:21-22. By using the historical-critical method, the author intends to underline the main message of Luke 3:21-22 that witnesses Jesus Christ as the Son of God. His identity comes from God Himself. At the baptism in the Jordan river, God declared before many people that Jesus was His beloved Son. The identity of Jesus as the Son of God reveals a special relationship between Jesus and His Father. The relationship is not a biological relationship between father and son, but a divine one. Jesus is the Son of God who was anointed to bring salvation to mankind.
\end{abstract}

\begin{abstract}
ABSTRAK:
Tulisan ini hendak mendiskusikan tentang Identitas Yesus Sebagai Anak Allah menurut Lukas 3:21-22. Dengan menggunakan metode historis-kritis, penulis ingin menggarisbawahi pesan utama dari teks Luk 3:21-22 bahwa Yesus Kristus adalah Anak Allah. Identitas-Nya itu berasal dari Allah sendiri. Pada saat pembaptisan di sungai Yordan, Allah memaklumkan di hadapan banyak orang bahwa Yesus adalah Anak-Nya yang terkasih. Identitas Yesus sebagai Anak Allah menyingkapkan sebuah relasi istimewa antara Yesus dan Bapa-Nya. Relasi tersebut bukan sebuah relasi biologis antara seorang ayah dan anak, melainkan sebuah relasi ilahi. Yesus adalah Anak Allah yang diurapi untuk membawa pembebasan bagi umat manusia.
\end{abstract}

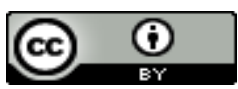

This work is licensed under a Creative Commons Attribution 4.0 International License

\section{Pengantar}

Istilah anak Allah merupakan gelar yang sering dipakai oleh kerajaan-kerajaan kuno untuk para raja. Para raja dipandang sebagai mereka yang diurapi dan dipilih oleh Tuhan untuk memimpin rakyat. Rick Brown menyebutkan bahwa Caesar Agustus juga mendapat gelar sebagai Anak Allah. Gelar Allah yang tersemat pada para raja atau kaisar di 
satu sisi berarti mereka memiliki keilahian menyetujui otoritas atas rakyat mereka, dan mereka sendiri tidak tunduk pada siapa pun kecuali Tuhan. ${ }^{1}$

Di dalam Kitab Suci, baik Yahudi maupun Kristen, istilah “anak Allah” merupakan istilah umum. ${ }^{2}$ Istilah Anak Allah ini multi arti. Pertama, istilah tersebut menunjuk pada hubungan Allah dengan orang pilihannya. Dalam kisah perjanjian Lama, Allah adalah Bapa bagi umat Israel (Kel. 18:22; Ul. 32:6; Yer. 31:9) karena Allah menjaga dan memelihara mereka, dan sebagai bentuk ketaatan, mereka menyebut Allah sebagai Bapa mereka. Raja Daud juga disebut sebagai anak Allah karena ia dipilih dan diurapi oleh Tuhan untuk memimpin bangsa Israel. Kedua, istilah itu menunjuk pada hubungan Allah dan para Malaikat. Ketiga, istilah itu secara Eksplisit menunjuk pada hubungan Allah dengan Yesus Kristus. Yesus Kristus dipandang sebagai Anak Allah, dan paling banyak ditampilkan dalam Perjanjian Baru.

Arti ketiga yang menunjuk pada identitas Yesus selaku Anak Allah seringkali menimbulkan perbantahan, bahkan sejak zaman Yesus. Orang-orang Yahudi masih meragukan identitas tersebut, bahkan menjadikannya sebagai alasan untuk menyalibkan Dia (Mat. 26:63; Mrk. 14:61; Luk. 22:70). Tak hanya di kalangan Yahudi, identitas keputeraan Yesus itu terus dipertanyakan oleh orang-orang yang tidak mengenal-Nya. Pertanyaan yang lazim terungkap, yakni Benarkan Yesus sungguh Anak Allah? Bagaimana mempertanggungjawabkan kebenaran itu?

Lukas salah seorang dari keempat penulis Injil ingin mempertanggungjawabkan kebenaran itu. Dalam teks Lukas 3:21-22, Lukas mengisahkan bahwa Yesus secara resmi diumumkan dan diperkenalkan sebagai Anak Allah di hadapan orang banyak yang berkumpul. Lukas paham dengan baik konteks beriman orang Israel bahwa langit (surga) merupakan tempat kediaman Allah yang Mahatinggi. ${ }^{3}$ Dengan menyebut suara dari langit, maka Lukas menegaskan bahwa Bapa yang memprakarsai dan memperkenalkan Yesus sebagai Anak-Nya sendiri. Dengan demikian, legalitas identitas Yesus selaku Anak Allah merupakan sebuah kebenaran yang berasal dari Allah sendiri.

\section{Teks Injil Lukas 3:21-22}

21 Ketika seluruh orang banyak itu telah dibaptis dan ketika Yesus juga dibaptis, dan sedang berdoa, terbukalah langit,

\footnotetext{
${ }^{1}$ Rick Brown, "The 'Son of God' Understanding the Messianic Titles of Jesus," International Journal of Frontier Missions 17, no. 1 (2000): 44.

2Ungaran@Rashid, “Jesus (pbuh) as 'son of God': A Biblical Study Based on the Jewish Scriptures and the Gospel of Matthew," t.t., https://journals.iium.edu.my/al-itqan/index.php/al itqan/article/view/118/50. ${ }^{3}$ Kata langit atau Surga dalam Kitab Suci sering dipakai untuk menujukkan tempat kediaman Allah, dan orang-orang yang dekat dengan Allah. Dalam Tradisi Bangsa Israel, mereka berdoa kepada Allah yang ada di Surga (Ul. 26:15). Allah itu merupakan pemilik langit dan bumi. "Langit," dalam Ensiklpodi Masa Kini Jilid II (Jakarta: Yayasan Komunikasi Bina Kasi, 2011) (Judul asli: The New Bible Dictionary).
} 
22 dan turunlah Roh Kudus dalam rupa burung merpati ke atas-Nya. Dan terdengarlah suara dari langit: "Engkaulah Anak-Ku yang kukasihi kepada-Mulah Aku berkenan."

\section{Struktur Teks}

Kisah pemakluman Yesus sebagai Anak Allah didahului dengan kisah pembaptisan orang banyak oleh Yohanes Pembaptis. Kisah ini seperti halnya yang terdapat dalam Injil Matius dan Markus. Namun bedanya Lukas tampak menegaskan dengan kuat mengenai Yesus sebagai salah satu dari orang banyak. ${ }^{4}$ Dengan cara ini, Lukas mau mengungkapkan bahwa Yesus turut ambil bagian dalam kehidupan orang banyak. Lukas juga menunjukkan sebuah perbedaan yang khas yang kemudian banyak muncul dalam Injilnya, yakni Yesus yang berdoa. Tindakan berdoa yang dibuat oleh Yesus inilah yang kemudian disertai dengan turunnya Roh Kudus, dan Pengakuan Bapa akan identitas diri Yesus sebagai anak-Nya. ${ }^{5}$

Kisah pembaptisan Yesus dan pemakluman identitas diriNya sebagai Anak Allah sebenarnya merupakan teks yang amat singkat. Namun teks yang amat singkat ini dapat dipilah-pilah menjadi dua bagian. Pertama, pengantar (ayat 21). Pada bagian ini, Lukas memberikan gambaran mengenai situasi umum yang terjadi di sungai Yordan. Kala itu, orang banyak berkumpul dan dibaptis. Yesus turut ditampilkan sebagai seorang yang paling terakhir dibaptis. Pasca pembaptisan itu ditunjukkan pula sikap Yesus yang berdoa sebagai point penting dalam pembaptisan Yesus. ${ }^{6}$ Sesudah itu, ditampilkan mengenai situasi alam di mana langit terbuka untuk menegaskan kuasa doa Yesus. Kedua, isi kisah mengenai peristiwa turunnya Roh Kudus atas diri Yesus dan pemakluman identitas Yesus oleh Bapa (ayat 22). Peristiwa turunnya Roh Kudus menjadi sangat penting karena denganNya Yesus memenuhi syarat untuk tugas dan pelayananNya sebagai Anak Allah di tengah dunia. Menurut Dr. Lightfoot peristiwa turunnya Roh Kudus amat penting karena menegaskan demonstrasi yang penuh, murni dan masuk akal tentang Allah Tritunggal di Sungai Yordan di mana Roh Kudus turun dan tinggal atas diri Yesus. ${ }^{7}$ Bersamaan dengan peristiwa itu, Bapa memaklumkan identitas Yesus sebagai Anak yang dikasihi dan memperoleh perkenanan (22c). Menurut CCD (Confraternity of Christian Doctrine), puncak dari focus dalam episode pembaptisan Yesus, yakni pemakluman Yesus sebagai Anak Allah oleh Suara dari Surga. ${ }^{8}$

\section{Konteks Kisah}

Episode pengakuan dan penegasan identitas Yesus sebagai Anak Allah merupakan lanjutan kisah pembaptisan di sungai Yordan. Untuk itu, Lukas mengawali episode ini

\footnotetext{
4 B.J. Boland, T afsiran Alkitab Injil Lukas (Jakarta: Gunung Mulia, 1999), 86.

5 Boland, 87.

${ }^{6}$ Confraternity of Christian Doctrin (CCD), Holy Bible: The New American Bible (United States of America: Catholic Bible Publisher, 1994), 1098.

${ }^{7}$ Mathew Hendry, Comentary on The Whole Bible Volume 6 (Grand Rapids: Christian Classics Ethereal Library, 1999), 1080.

${ }^{8}$ Confraternity of Christian Doctrin (CCD), Holy Bible, 1098.
} 
dengan menggambarkan bahwa di Sungai Yordan, orang banyak dibaptis. Pembaptisan tersebut merupakan persiapan untuk menyambut Yesus, Anak Allah. Pembaptisan di Sungai Yordan tersebut kemudian dipuncaki dengan pembaptisan Yesus. ${ }^{9}$ Pembaptisan Yesus merupakan momen penting karena pada saat itu, Allah mengakui bahwa Yesus merupakan Anak yang amat dikasihi-Nya.

Konteks pemakluman Yesus sebagai Anak Allah ada dalam sebuah rentetan kisah yang amat panjang. Pemakluman ini tidak serta-merta muncul begitu saja, namun berkaitan dengan kisah-kisah sebelumnya dan sesudahnya. Hal mana ditegaskan juga oleh Komisi Kitab Suci Kepausan: "Salah satu hal yang membuat Alkitab memiliki kesatuan internal yang unik adalah kenyataan bahwa tulisan-tulisan alkitabiah yang lebih kemudian sering tergantung pada tulisan-tulisan yang lebih awal." 10 Itu berarti teks mengenai pemakluman Yesus sebagai Anak Allah berada dalam kesatuan yang unik dengan teks-teks sebelumnya maupun sesudahnya.

Dalam konteks Injil Lukas secara khusus, pemakluman identitas Yesus sebagai Anak Allah memang sudah dimulai oleh Lukas di awal Injilnya melalui pemberitaan Malaikat Gabriel kepada Maria. Gabriel memberitakan bahwa Maria akan mengandung dan melahirkan seorang anak-anak laki yang akan dinamai Yesus, dan Ia akan menjadi besar dan akan disebut Anak Allah yang Mahatinggi (Luk. 1:31-32). Pemberitaaan Malaikat Gabriel sebenarnya mau mengungkapkan bahwa eksistensi Yesus sebagai Anak Allah sudah diumumkan sebelum peristiwa inkarnasi. Ia sungguh-sungguh adalah Anak Allah yang akan dilahirkan. Ia akan berada dalam kandungan Maria seorang perawan, dengan kekuatan Roh Kudus. Ia datang untuk membawa pembaharuan radikal sebagai tindakan penyelamatan dari Allah Bapa. ${ }^{11}$

Elisabeth, Ibu Yohanes Pembaptis, juga turut menegaskan eksistensi Yesus sebagai Anak Allah. Ia berkata, "Siapakah aku ini sampai ibu Tuhanku datang mengunjungi aku (Luk. 1:43). Penegasan Elisabeth ini sebenarnya sebuah penegasan retoris karena dirinya dipenuhi oleh Roh Kudus. Kendati demikian, menurut Stefan Leks pernyataan ini merupakan sebuah pengakuan akan Yesus sebagai Mesias yang dijanjikan Allah. ${ }^{12}$ Mesias, merupakan sosok raja yang ideal. ${ }^{13}$ Ia adalah Tuhan yang dinanti-nantikan, dan Yesus yang ada dalam kandungan Maria merupakan sosok itu (bdk. Luk. 2:26).

Identitas Yesus sungguh terungkap ketika peristiwa kelahiran-Nya. Malaikat memberitahukan kepada para gembala bahwa yang dilahirkan itu sungguh ialah Kristus, Tuhan. Para malaikat kemudian mengunjungi bayi Yesus, dan memuji Tuhan atas peristiwa

\footnotetext{
${ }^{9}$ Boland, Tafsiran Alkitab Injil Lukas, 87.

${ }^{10}$ Komisi Kitab Suci Kepausan, Penafsiran Alkitab dalam Gereja (Yogyakarta: Kanisius, 2003), 117.

${ }^{11}$ Lembaga Biblika Indonesia, Tafsir Alkitab Perjanjian Baru (Yogyakarta: Kanisius, 2002), 117.

12 Stefan Leks, Tafsir Injil Lukas (Yogyakarta: Kanisius, 2003), 55.

13 Istilah Mesias merupakan gelar resmi yang dipakai untuk tokoh utama yang dinanti-nantikan oleh orang Yahudi. Istilah ini sebenarnya sudah muncul dalam teks Perjanjian Lama namun dikukuhkan dalam Perjanjian Baru. Dalam Perjanjian Baru, istilah Mesias secara Eksplisit menunjuk pada Yesus dari Nasareth. Yesus adalah Mesias dari Suku Daud (Mrk 1:11), Anak Allah yang Mahatinggi. Mesias adalah hamba yang rendah hati, taat, menderita, menggenapi tugasnya dengan menjalani maut, sambil menyerahkan pembelaan diri atas-Nya kepada Allah dengan hati yang percaya. Yayasan Komunikasi Bina Kasih, "Mesias," dalam Ensiklopedi Alkitab Masa Kini Jilid II (Jakarta: Yayasan Komunikasi Bina Kasih, 2011).
} 
tersebut. Peristiwa kelahiran Yesus ini menggenapi pemberitaan Malaikat Gabriel akan datang-Nya Yesus sebagai Anak Allah. Identitas Yesus dan segala berita yang disampaikan malaikat kemudian diceritakan, dan menimbulkan keheranan bagi mereka yang mendengarnya.

Ketika masih berumur 12 tahun Yesus memperkenalkan diri-Nya kepada kedua orang tuanya melalui pernyataan retoris yang dikemukakannya "Mengapa kamu mencari Aku? Tidak kamu tahu, bahwa Aku harus berada dalam rumah BapaKu? (Luk. 2:49). Yesus mau menegaskan bahwa Ia sungguh Anak Allah, dan ia datang untuk menjalankan misi Allah. Ia memiliki hubungan mesra dengan Bapa-Nya. Hubungan ini merupakan sebuah hubungan yang jauh melampui kesadaran agamawi dalam kehidupan orang Yahudi, ${ }^{14}$ dan Anak Allah harus berada di rumah Bapa-Nya. Tetapi momen perkenalan Yesus ini belum dipahami oleh kedua orang tua-Nya. Kendati demikian, ucapan Yesus kepada kedua orang tuanya mempertegas apa yang dikatakan Malaikat sebelum kelahiran-Nya. Yesus adalah Anak Allah. ${ }^{15}$

Yohanes Pembaptis sebagai Nabi yang pada masa itu sangat dikagumi melanjutkan pewartaan perihal identitas Yesus. Ia berkata: "Aku membaptis kamu dengan air, tetapi Ia yang lebih berkuasa dari pada-Ku akan datang dan membuka tali kasut-Nya pun aku tidak layak. Ia akan membaptis kamu dengan Roh Kudus dan dengan api (Luk. 3:16)." Yohanes berusaha menjawab kegelisahan banyak orang yang mengira bahwa ia adalah Mesias. Oleh karena itu, ia memperkenalkan dirinya bahwa ia bukanlah Mesias, yang mereka nantikan. Ia hanyalah Nabi, tetapi Yesus adalah sang Mesias, Anak Allah yang Mahatinggi. Yesus memiliki kuasa yang jauh melampaui Yohanes, bahkan untuk menyentuh tali kasutnya pun Yohanes tak layak. Yesus membaptis orang dengan Roh Kudus, dan berbeda dengan Yohanes yang hanya membaptis dengan air. Perbedaan-perbedaan yang ditunjukan Yohanes itu ingin mempertegas identitas Yesus bahwa ia berasal dari Allah. Pewartaan Yohanes ini merupakan jalan masuk pada puncak penegasan identitas Yesus oleh Allah sendiri.

Puncak dari semua pemakluman identitas Yesus terungkap ketika Yesus besar sesuai pemakluman Malaikat Gabriel. Lukas mengisahkan hal itu dengan amat menarik. Ia menempatkan Yesus sebagai yang terakhir dibaptis, sesudah orang banyak. ${ }^{16}$ Sesudah dibaptis, Yesus berdoa, dan pada saat itulah Allah memaklumkan identitas Yesus sebagai Anak-Nya yang dikasihi. Pengakuan ini serentak menegaskan keistimewaan Yesus. Yesus berbeda dari mereka yang lain yang turut dibaptis. Ia merupakan Anak Allah.

Pewartaan-pewartaan mengenai pengakuan identitas Yesus amat menarik karena pengakuan tersebut senantiasa ditandai dengan inisiatif dari Allah dan berpuncak pada pengakuan dari Allah sendiri. Allah memprakarsai dan menggunakan berbagai macam cara dan beragam tokoh (Malaikat, Maria, Elisabet, para gembala, Simeon dan Hana, Yesus, dan Yohanes Pembaptis sang Nabi Allah) untuk menegaskan identitas Yesus. Semua ini kemudian dipuncaki dengan pengakuan dari Allah sendiri "Engkaulah Anak-Ku yang Kukasihi Kepada-Mulah Aku Berkenan (Luk. 3:22). Penegasan Allah tentang Yesus

\footnotetext{
14 Yayasan Komunikasi Bina Kasih, Tafsiran Alkibat Masa Kini 3 (Jakarta: BPK Gunung Mulia, 2012), 195.

15 Robert C. Tannehill, The Narrative Unity of Luke-Acts a Literary Interpretation (Philladelphia: Forter Press, 1986), 55.

${ }^{16}$ Lembaga Biblika Indonesia, Tafsir Alkitab Perjanjian Baru, 122.
} 
kemudian diakui oleh Yesus menjelang wafatnya: Ya Bapa, ke dalam tangan-Mu Kuserahkan nyawa-Ku (Luk.23:46).

Konteks pemakluman identitas Yesus sebagai anak Allah ditempatkan dalam sebuah kisah perjalanan Yesus. Perjalanan Yesus dimulai dengan meninggalkan Nasareth di Galilea tempat Ia dibesarkan, dan berangkat ke wilayah kerja Yohanes Pembaptis, yakni sungai Yordan. Kala itu, sungai Yordan merupakan tempat di mana banyak orang berkumpul. Mereka datang berziarah seraya memberikan dirinya dibaptis oleh Yohanis Pembaptis. ${ }^{17}$ Di tempat yang dikunjungi banyak orang itu, Allah memaklumkan Yesus, sebagai Anak Allah. Episode pengakuan terhadap identitas Yesus menunjukkan bahwa tampaknya Lukas menempatkan seluruh kisah hidup Yesus melalui injilnya dalam konteks gelar Yesus sebagai Anak Allah. Yesus sebagai anak Allah merupakan utusan Tuhan, untuk menyelamatkan mereka yang hilang. ${ }^{18}$

\section{Keaslian Teks}

Persoalan yang dihadapi di sini ialah, apakah teks Lukas 3:21-22 tentang identitas Yesus sebagai Anak Allah sungguh-sungguh asli? Keaslian teks ini amat penting karena turut menentukkan kebenaran kisah Lukas. Keaslian teks ini dapat ditelusuri dengan menggunakan metode kritiks teks. Kritik teks memiliki fungsi ganda, yakni merekontstruksi kejadian dari teks Alkitabiah dan melacak penyampaian teks selama berabad-abad. ${ }^{19}$

Teks Lukas tentang identitas Yesus sebagai Anak Allah terbagi atas dua ayat, yakni ayat 21 dan 22. Ayat 21 tidak bermasalah mengenai keasliannya. Para ahli tidak memperdebatkan ayat ini. Persoalan justru muncul pada ayat $22 .{ }^{20}$ Bruce Metzger dalam " $A$ Textual Comentary On The Greek New Testament"menampilkan persoalan pada ayat 22 itu. ${ }^{21}$ Teks Lukas yang digunakan saat ini berbunyi: "Engkaulah Anak-Ku yang Kukasihi, kepada-Mulah aku berkenan." Menurut Metzger teks ini berbeda dengan teks yang beredar pada tiga abad pertama, yang berbunyi "Pada hari ini, Aku telah memperanakan Engkau." 22 Teks tua itu menurut sebagian ahli Kitab Suci merupakan teks yang asli dibandingkan dengan teks ayat 22 saat ini. Dalam teks itu, ada dua penekanan penting, yakni "pada hari ini” dan "Aku memperanakan Engkau". Makna dua penekanan itu, yakni pada hari itu Yesus diadopsi atau diangkat sebagai anak Allah. Rupanya yang ingin ditegaskan dalam teks tersebut ialah hari pembaptisan Yesus menjadi hari yang penting karena pada saat itulah Yesus diangkat sebagai Anak Allah. Pernyataan itu seolah-olah menempatkan identitas Yesus sebagai sekedar pemberian kemudian. Konsekuensinya, identitas Anak Allah, bukanlah sebuah identitas yang melekat sejak awal tetapi gelar yang diberikan kemudian. ${ }^{23}$

\footnotetext{
${ }^{17}$ Lembaga Biblika Indonesia, 122.

18 Raymond A. Brown, An Introduction To The New Testament (New York: Double Day, 1997), 235.

${ }^{19}$ Lembaga Biblika Indonesia, Tafsir Alkitab Perjanjian Lama (Yogyakarta: Kanisius, 2002), $24-25$.

${ }^{20}$ Kurt Aland dkk, The Greek New Testament (Stutgart: Fortress Press, 1998), 53.

21 Aland dkk, 53.

${ }_{22}$ Bruce M. Metzger, A Textual Comentary On The Greek New Testament (New York: United Bible Societis, 2005), 136.

23 Boland, Tafsiran Alkitab Injil Lukas, 88.
} 
Di sisi lain, pernyataan itu menempatkan gelar anak Allah pada Yesus hanya sebagai gelar fungsional, yakni untuk melakukan karya pelayanan Allah

Tetapi menurut Metzger, teks tua tersebut berasal dari sumber sekunder, yang tak lain ialah teks Maz. 2:7, yang memiliki bunyi yang sama, yakni "Engkau telah Kuperanakan pada hari ini." Metzger melihat bahwa ada sumber primer. Sumber primer itulah yang digunakan pada Injil Lukas sampai saat ini, dan juga muncul dalam teks Mat. 3:17, dan Mrk. 1:11. Dalam teks Lukas maupun kedua teks lain, terdapat penegasan penting bahwa Yesus adalah Anak Allah yang dikasihi, dan kepada-Nyalah Allah berkenan. Tampak di sini perbedaan yang khas antara teks tua dengan teks yang digunakan oleh Lukas, Markus dan Matius. Ketiganya tidak memberikan penekanan pada konteks temporal pengakuan itu. Mereka justru memberikan penegasan bahwa Yesus sungguh adalah Anak Allah yang dikasihi. Ia tidak hanya diadopsi atau diangkat sebagai Anak Allah pada hari pembaptisan itu, tetapi sudah sejak awal Yesus adalah Anak Allah.

Boland membenarkan pandangan bahwa teks Lukas ayat 22 yang digunakan saat ini merupakan teks asli. Ia mengingatkan bahwa dengan mengutip Mzm 2:7 dalam Perjanjian Baru, maka tekanan selalu terletak pada pernyataan, "Engkaulah Anak-Ku", dan bukan pada pernyataan, "pada hari ini." Lukas memberikan penekanan pada proklamasi identitas Yesus oleh Bapa, dan tidak memberikan penekanan pada hari di mana Yesus diakui. Bagi Lukas yang terpenting ialah Yesus adalah Anak Allah sejak semula, bahkan identitas ini sudah diberitahukan kepada Maria oleh Malaikat Gabriel sebelum Maria mengandung. ${ }^{24}$ Penegasan itu secara tegas menunjukkan bahwa identitas Yesus sebagai Anak Allah melekat secara ontologis maupun fungsional pada Yesus. ${ }^{25}$ Disebut ontologis karena gelar itu memang sudah ada pada Yesus sebelum peristiwa inkarnasi. Disebut fungsional, karena Yesus datang sebagai Anak Allah untuk menjalankan misi besar, yakni menyelamatkan umat manusia. Ia diurapi oleh Allah untuk menjalankan misi besar itu.

\section{Bersumber Dari Markus}

Isi teks Injil Lukas ayat $3: 21-22$ sebenarnya terdapat pula dalam ketiga injil lain, yakni dalam Mrk. 1:9-11, Mat. 3:13-17 dan Yohanes 1:29-34. Secara lugas, teks-teks itu menunjuk pada Yesus sebagai Anak Allah. Keempat penulis sama-sama sepakat akan identitas Yesus. Yesus adalah Anak Allah dengan Roh di atas kepalanya pada saat pembaptisan di sungai Yordan. Apakah itu berarti Lukas mereferensi Injil lain?

Menurut para ahli Kitab Suci, Lukas menggunakan Sumber Markus dalam menyusun teksnya. ${ }^{26}$ Bagaimana dengan teks-teks Matius dan Yohanes? Lukas barangkali langsung merujuk pada sumber Markus, dan tidak menggunakan teks Matius dan Yohanes. ${ }^{27}$ Hal itu kelihatan dalam teks yang dipakai oleh Matius, khususnya ayat 14 dan 15 dalam Injil Matius. Perdebatan dalam Injil Matius antara Yesus dan Yohanes Pembaptis tidak

\footnotetext{
${ }^{24}$ Metzger, A Textual Comentary, 136.

${ }^{25}$ Brown, "The 'Son of God' Understanding," 44.

${ }^{26}$ Carl R. Holladay, A Critical Introduction To The New Testament (United States Of America: Abingdon Press, 2005), 228.

27 Boland, Tafsiran Alkitab Injil Lukas, 81.
} 
ditampilkan oleh Lukas dalam tulisannya. ${ }^{28}$ Lukas juga tidak mungkin menggunakan sumber Injil Yohanes karena diperkirakan bahwa Injil Yohanes ditulis sesudah Injil sinoptik, yakni antara tahun 90 Masehi. ${ }^{29}$ Di samping itu, penyajian isi yang terkandung dalam Injil Yohanes tampak agak berbeda dengan ketiga Injil sinoptik, khususnya Injil Lukas. Jika ketiga Injil Sinoptik merujuk pada suara dari langit, maka Yohanes justru merujuk pada kesaksiannya sendiri tentang Yesus sebagai Anak Allah. Dengan demikian, Lukas memang menggunakan sumber Markus dalam tulisannya.

Data di atas kemungkinan benar karena Lukas menulis Injil antara tahun 80-90, sesudah penghancuran Kota Yerusalem oleh Titus pada tahun 70. Injil Markus justru sebaliknya ditulis lebih dahulu, yakni antara tahun 65-70. Tampak bahwa Markus sudah menulis Injilnya terlebih dahulu, Injil tersebut ditujukan untuk umat dan Data lain yang juga turut menguatkan fakta ini ialah apa yang tertulis dalam prolog Injil Lukas. Lukas mengakui bahwa dalam menulis Injil-nya, ia mengumpulkan berbagai sumber dan menyeledikinya dengan seksama. Penyeledikan ini kemudian berujung pada keputusan untuk membukukan secara teratur bagi Teofilus yang mulia (bdk. Luk. 1:1-3).

Benar bahwa Lukas menggunakan sumber Markus. Namun kebenaran ini perlu ditelusuri lebih jauh dengan menyelidiki kesamaan dalam teks-teks tersebut.

Persamaan Perikop Injil Markus dan Lukas

\begin{tabular}{|l|l|l|}
\hline Mark. 1:9-11 & \multicolumn{1}{|c|}{ Unsur-unsur Kesamaan } & Luk. 3:21-22 \\
\hline $1: 9 \mathrm{~b}$ & Yesus dibaptis & $3: 21 \mathrm{a}$ \\
\hline $1: 10 \mathrm{a}$ & Langit yang terbuka/terkoyak & $3: 21 \mathrm{~b}$ \\
\hline $1: 10 \mathrm{c}$ & Roh dalam rupa burung merpati turun ke atas Yesus & $3: 22 \mathrm{~b}$ \\
\hline $1: 11 \mathrm{a}$ & Terdengarlah Suara dari langit/surge & $3: 22 \mathrm{~b}$ \\
\hline $1: 11 \mathrm{~b}$ & $\begin{array}{l}\text { "Engkaulah anak-Ku yang kasihi kepadaMulah aku } \\
\text { berkenan }\end{array}$ & $3: 22 \mathrm{c}$ \\
\hline
\end{tabular}

Kesamaan-kesamaan tersebut memperlihatkan bahwa Lukas sebenarnya menggunakan sumber Markus. Lukas dan Markus sama-sama sepakat bahwa Yesus dibaptis, dan pada saat itu langit terkoyak dan turunlah Roh Kudus dalam rupa burung merpati ke atas Yesus. Sesudah peristiwa itu, kedua penginjil sama-sama menunjuk pada suara yang terdengar dari langit/surga, dan promulgasi Allah bahwa Yesus adalah anakNya yang dikasihi dan hanya kepadaNyalah Ia berkenan. Persamaan penegasan "Engkaulah Anak-Ku” dalam Injil Markus dan Lukas menunjuk pada kepunyaan orang pertama tunggal.

\footnotetext{
${ }^{28}$ Memang menurut para ahli Lukas menggunakan sumber Markus dan Matius, namun dalam teks konteks Kisah Pembaptisan Yesus Lukas hanya menggunakan sumber Markus, dan bukan Matius.

${ }^{29}$ Yayasan Komunikasi Bina Kasih, Tafisiran Alkitab Masa Kini (Judul Asli: The New Bible Commentary) (Jakarta: Yayasan Komunikasi Bina Kasi, 1982), 260.
} 
Teks ini mengingatkan kita pada teks Mzm. 2:7 di mana ungkapan itu menunjuk pada Raja yang diurapi. Dalam konteks pemakluman identitas Yesus ingin ditegaskan bahwa Yesus diurapi oleh Allah dan Ia adalah Anak Allah. ${ }^{30}$

Berdasarkan gambaran-gambaran di atas tampak bahwa unsur-unsur menyangkut isi, bahasa dan pola cerita yang digunakan oleh Lukas dan Markus, memiliki kemiripan. Dengan demikian, ada kedekatan erat antara kisah Lukas dan Markus. Lukas benar-benar menggunakan sumber Markus.

Lewat kemiripan tersebut, Lukas ingin menegaskan bahwa data-data yang dipakainya bukanlah sebuah hasil rasionalisasi. Justru sebuah kebenaran yang diselidiki bahwa Yesus sungguh Anak Allah. Karena itulah para ahli membenarkan kukuhnya informasi yang disampaikan oleh Lukas. Kendati demikian, perlu diingat bahwa Lukas senantiasa melihat data Markus tentang Yesus dalam terang iman. Ia tidak hanya menggambarkan Yesus secara historis, namun memasukan janji keselamatan universal, yang dengannya identitas Yesus sebagai Anak Allah diperjelas. ${ }^{31}$

Meskipun teks Markus dan Lukas memiliki kemiripan, namun tidak persis sama. Artinya ada perbedaan antara teks Markus dan teks Lukas. Tidak semua teks yang termuat dalam Injil Markus termuat dalam Injil Lukas, dan demikian pula sebaliknya. Tidak semua teks Injil Lukas termuat dalam Injil Markus. Adapun hal itu terlihat lewat perbedaanperbedaan yang terkandung dalam kedua teks.

\section{Perbedaan Perikop Injil Markus dan Lukas}

\begin{tabular}{|c|l|c|}
\hline Mark. 1:9-11 & \multicolumn{1}{|c|}{ Unsur-unsur perbedaan } & Luk. 3:21-22 \\
\hline $\begin{array}{c}\text { Yesus melakukan } \\
\text { perjalanan dari } \\
\begin{array}{c}\text { Nazareth di tanah } \\
\text { Galilea }\end{array}\end{array}$ & $\begin{array}{l}\text { Markus mengisahkan perjalanan Yesus, } \\
\text { sedangkan Lukas hanya menyebut } \\
\text { bahwa Yesus dibaptis. }\end{array}$ & $\begin{array}{c}\text { Yesus sudah } \\
\text { berada di tempat } \\
\text { pembaptisan }\end{array}$ \\
\hline Yesus dibaptis & $\begin{array}{l}\text { Markus hanya menyebut pembaptisan } \\
\text { Yesus, sedangkan Lukas menyebutkan } \\
\text { bahwa Yesus juga ikut dibaptis bersama } \\
\text { orang banyak }\end{array}$ & $\begin{array}{c}\text { Yesus dibaptis } \\
\text { bersama orang } \\
\text { banyak }\end{array}$ \\
\hline $\begin{array}{l}\text { Yesus keluar dari } \\
\text { air }\end{array}$ & $\begin{array}{l}\text { Markus menegaskan bahwa sesudah } \\
\text { dibaptis Yesus keluar dari Air, Lukas } \\
\text { malah menegaskan bahwa sesudah } \\
\text { dibaptis Yesus berdoa. }\end{array}$ & Yesus berdoa \\
\hline
\end{tabular}

\footnotetext{
${ }^{30}$ Boland, Tafsiran Alkitab Injil Lukas, 88.

${ }^{31}$ Lembaga Biblika Indonesia, Tafsir Alkitab Perjanjian Baru, 121.
} 


\begin{tabular}{|l|l|c|}
\hline Terkoyak & $\begin{array}{l}\text { Markus cenderung menggunakan kata } \\
\text { yang agak kasar, Lukas malah memilih } \\
\text { kata yang halus. }\end{array}$ & Terbuka \\
\hline
\end{tabular}

Markus secara eksplisit menggambarkan bahwa Yesus sedang dalam perjalanan dari Nazareth di tanah Galilea, dan dibaptis oleh Yohanes Pembaptis. Sesudah dibaptis, Yesus kemudian keluar dari air, dan pada saat itulah langit terkoyak dan terdengarlah suara dari surga bahwa Yesus adalah anak Allah.

Berdasarkan gambaran tersebut, tampaknya Markus ingin menekankan hal yang berbeda dengan Lukas. Markus menampilkan kisah pembaptisan Yesus dalam konteks sebuah perjalanan panjang, di mana Yesus keluar dari kampung halamannya untuk dibaptis oleh Yohanes Pembaptis. ${ }^{32}$ Rupanya Markus tidak hanya memberikan gambaran historis dan tata letak sebuah lokasi, namun juga sebuah perspektif bahwa Yesus dalam memulai karirnya senantiasa ditandai dengan " keluar" untuk menunjukkan jati dirinya sebagai Anak Allah. Ia bahkan harus keluar dari kampung halaman-Nya untuk menggenapi Rencana Allah. ${ }^{33}$ Gerakan "keluar" inilah yang kemudian muncul juga sesudah pembaptisan. Sesudah dibaptis, Yesus "keluar" dari air dan pada saat itulah Roh Kudus tampak dalam rupa burung merpati. Sesudah itu, Allah membelah langit sehingga terkoyak dan dari dalamnya terdengarlah suara pengakuan bahwa Yesus merupakan Anak Allah. Rupanya gerakan keluar memiliki peranan penting dalam teologi Markus, sehingga Markus menegaskan hal tersebut. Tampak pula bahwa Markus menganggap peranan Yohanes amat penting. Untuk itu, peranan Yohanes ditonjolkan di awal teksnya. Yohanes bertugas untuk menunjuk pada Yesus sang Mesias. ${ }^{34}$ Bagi Markus, peranan Yohanes dianggap amat penting untuk membuka jalan dan menegaskan keberadaan Yesus. Yohanes yang pada saat itu tampil sebagai seorang yang berwibawa dan suaranya pasti akan semakin menegaskan identitas Yesus.

Lukas justru menampilkan hal yang berbeda dengan Markus. Lukas tidak secara eksplisit menggambarkan perjalanan Yesus, bahkan Lukas menggambarkan bahwa pada saat itu Yesus sudah berada di tempat pembaptisan tersebut dan dibaptis bersamaan dengan orang banyak. Lukas bahkan tidak menyebut nama Yohanes Pembaptis dalam tulisannya, justru yang ditonjolkan adalah Yesus. Pembaptisan Yesus bahkan ditempatkan paling akhir dibanding yang lain. Sesudah itu, Lukas tidak menggambarkan bahwa Yesus keluar dari air. Lukas justru menekankan pada sikap Yesus sesudah pembaptisan, yakni berdoa. Melalui doa Yesus, Roh dalam rupa burung Merpati turun dari langit dan terdengarlah sebuah pengakuan bahwa Yesus merupakan anak Allah yang berkenan kepada-Nya. Fakta ini memberikan gambaran bahwa Lukas memang menggunakan sumber Markus, namun memodifikasi kembali dengan redaksi yang khas dirinya. Hal ini seturut dengan apa yang

\footnotetext{
32 Lembaga Biblika Indonesia, 121.

33 Stefan Leks, Tafsir Injil Markus (Yogyakarta: Kanisius, 2003), 41.

${ }^{34}$ Leks, 41.
} 
digambarkan oleh Fitzmyer dalam bukunya bahwa Lukas menggunakan sumber Markus, namun menyusun kembali dengan gaya khasnya. ${ }^{35}$

Berdasarkan data di atas tampak bahwa Lukas hendak memberikan penekanan pada beberapa hal penting. Penekanan tersebutlah yang kemudian membedakan Lukas dari Markus.

Pertama, Yesus menjadi salah satu dari orang banyak yang dibaptis. Hal itu berarti Yesus menggabungkan diri dengan para peziarah yang mau memberi diriNya dibaptis oleh Yohanes Pembaptis di Yordan. ${ }^{36}$ Lukas ingin menegaskan bahwa Yesus dalam keallahanNya sebagai Putera turut solider dengan manusia. Ia mengawali karya-Nya dengan melibatkan diri dalam kehidupan orang banyak. Ia adalah Anak Allah yang rendah hati dan memiliki sosialitas yang tinggi. ${ }^{37}$

Kedua, Lukas tidak secara eksplisit menunjuk bahwa Yesus dibaptis oleh Yohanes. Ketika berbicara tentang Yohanes Pembaptis Lukas sudah menegaskan bahwa Yohanes berada dalam penjara (Bdk. 3:20). Rupanya bagi Lukas yang terpenting bukanlah siapa yang membaptis namun Yesus benar dibaptis dan pada saat pembaptisan itulah, Ia ditegaskan sebagai Anak Allah. Momen pemakluman Yesus bagi Lukas, merupakan tanda bahwa Yesus telah mengambil panggung Yohanes. Yohanes sudah mempersiapkan, dan Yesus yang akan mengambil "panggung" itu, untuk menjalankan perannya sebagai Anak Allah. ${ }^{38}$

Ketiga, Yesus yang berdoa. Sikap Yesus sesudah pembaptisan yakni berdoa. Berdoa merupakan suatu hal penting yang ingin ditonjolkan oleh Lukas. Bagi Lukas, Yesus senantiasa menandai karyanya dengan doa. Bila melihat teks-teks lain dalam Injil Lukas, Lukas sebenarnya menegaskan hal yang sama, yakni Yesus yang berdoa dalam momenmomen pentingnya. Ketika memanggil para muridNya, Yesus mengawalinya dengan doa (Bdk. Luk. 6:12); Ketika Yesus menanyakan perihal dirinya kepada Para Murid, Yesus juga sudah menandainya dengan doa (Luk. 9:18); Dalam peristiwa transfigurasi di atas gunung, Yesus juga mengawalinya dengan berdoa (Luk. 9:28-29); Ketika mengajarkan mengenai perihal doa, Yesus juga sudah lebih dahulu mempraktikkan doa (Luk. 11:1). Di taman Getsemani, Yesus juga berdoa sebelum menghadapi penderitaanNya (Luk. 22:42); dan bahkan di atas Salib pun Yesus masih sempat berdoa dengan berkata "Ya Bapa, Ampunilah mereka karena mereka tidak tahu apa yang mereka perbuat (Luk. 23:34), dan bahkan di akhir hidupNya, Yesus berdoa sebagai tanda penyerahan diri-Nya kepada Bapa (Luk. 23:46)." Namun perlu diingat bahwa Yesus berdoa pula sebagai perantara keselamatan, sang Anak Allah. Dalam doa, Yesus membangun keintiman dengan Bapa dan Roh Kudus demi keselamatan umat manusia. ${ }^{39}$ Dengan demikian tampak bahwa Lukas menarik sebuah gambaran penting bahwa Yesus senantiasa menandai semua hal penting dalam hidup-Nya

\footnotetext{
${ }^{35}$ Fitzmyer, The Gospel Acording To Luke, 479-80.

${ }^{36}$ Lembaga Biblika Indonesia, Tafsir Alkitab Perjanjian Baru, 122.

${ }^{37}$ Boland, Tafsiran Alkitab Injil Lukas, 86.

${ }^{38}$ Leks, Tafsir Injil Lukas, 125.

${ }^{39}$ Leks, 125.
} 
dengan berdoa. Doa merupakan dialog sejati antara Yesus selaku Putera dengan, Bapa dan Roh Kudus. Karena itulah Yesus harus berdoa kepada-Nya. ${ }^{40}$

Keempat, peranan Roh Kudus yang ditonjolkan. Lukas mau menegaskan bahwa Roh Kudus memainkan perananan penting dalam karya dan kerja Yesus. ${ }^{41}$ Roh ini sebenarnya bukanlah hal baru dalam hidup Yesus. Justru sudah bersama dengan Yesus sejak dikandung oleh Perawan Maria sesuai dengan pemakluman Malaikat Gabriel. Roh ini akan senantiasa bersama dengan Yesus, dan momen pemakluman adalah kesempatan yang tepat, untuk mengungkapkan di hadapan orang banyak bahwa Roh Allah sungguh ada dalam diri Yesus selaku Anak Allah.

Kelima, penekanan Yesus sebagai Anak Allah dalam keadaan yang mutlak dan tak terbantahkan. Yesus menjadi Anak Allah bukan karena ia adalah Mesias, namun sebaliknya ia menjadi Mesias karena ia adalah Anak Allah. ${ }^{42}$ Mesias dalam zaman Perjanjian Lama dipandang sebagai tokoh yang dinanti-nantikan oleh orang Yahudi. Konsep mesianisme dalam Perjanjian Lama ini berhubungan dengan lima hal, yakni dipilih Allah (Yes 41:25), ditetapkan Allah untuk menggenapi suatu tujuan penyelamatan bagi umat Allah (Yes 45:1113), menggenapi hukuman terhadap musuh-musuh-Nya (Yes 47), diberikan kuasa untuk memerintah bangsa-bangsa (Yes 45:1-3), dan dalam segala tindakannya, yang sesungguhnya bertindak ialah Allah sendiri (Yes 45:1-7). Konsep Mesianisme Perjanjian lama tersebut secara eksplisit menunjuk pada sang tokoh penyelamat. Mesianisme Perjanjian Lama itu kemudian tergenapi dalam mesianisme Perjanjian Baru yang tampak dalam diri Yesus Kristus sendiri. Yesus memenuhi kelima unsur itu. Namun gelar mesianik itu baru disematkan kemudian karena keberadaan Yesus Putera Allah. Dengan kata lain, gelar Putera Allah mendahului gelar mesianiknya. Yesus adalah Putera Allah yang dipilih, diurapi dan datang untuk menyelamatkan umat manusia dari Kuasa Dosa. Di dalam dirinya ada kuasa untuk memimpin bangsa-bangsa, dan bertindak atas nama Allah. Lukas rupanya paham dan menyelidiki kebenaran ini, sehingga dengan berani mengatakan bahwa Yesus adalah Anak Allah. Lukas bahkan memberikan peneguhan yang kuat bahwa identitas itu berasal dari Bapa sendiri.

\section{Kisah Deklarasi Allah}

Peristiwa pembaptisan Yesus dan pemakluman identitas Yesus secara literer merupakan sebuah kisah. Kisah tentang Yesus yang dibaptis bersama dengan orang banyak. Kisah ini kemudian diberi bobot teologis, yakni turunnya Roh Kudus untuk menandai karya Yesus. ${ }^{43}$ Kisah ini kemudian diperindah dengan gambaran yang benar-benar profan, "dalam rupa burung merpati." 44 Ternyata untuk menunjukkan eksistensiNya, Lukas mengisahkan

\footnotetext{
40 Yayasan Komunikasi Bina Kasih, “Doa," dalam Ensiklopedi Masa Kini: Jilid 1A-L (Jakarta: Yayasan Komunikasi Bina Kasi, 2011).

41 Tannehill, The Narrative Unity of Luke-Acts, 57.

${ }^{42}$ Yayasan Komunikasi Bina Kasih, "Yesus Kristus," dalam Ensiklpodi Masa Kini Jilid II (Jakarta: Yayasan Komunikasi Bina Kasih, 2011).

${ }^{43}$ Leks, Tafsir Injil Lukas, 126.

${ }^{44}$ Lukas merupakan seorang penulis Injil yang tahu dengan baik lingkungan hidup orang Yunani, bahkan diduga bahwa ia menulis Injilnya untuk orang Kristen yang berlatarbelakang Yunani. Dalam kebudayaan Yunani, burung merpati mempunyai makna penting. Ketika burung merpati hinggap pada kepala seseorang,
} 
bahwa Allah menggunakan unsur-unsur ciptaanNya untuk dikenal manusia. Stefan Leks mengungkapkan bahwa Lukas menggunakan istilah dalam rupa merpati untuk menegaskan bahwa Roh Allah benar-benar turun atas Yesus. Roh Allah memang adikodrati, demikian pun dengan pengalaman Yesus benar-benar ajaib. Roh Allah digambarkan dalam rupa burung merpati karena merpati merupakan lambang ciptaan baru (Bdk. Kej. 1:2) dan pembebasan baru (Kej. 8:8) menurut Perjanjian Lama, dan dalam Perjanjian Baru, Merpati itu merupakan lambang kehadiran Roh Kudus dalam diri Yesus. ${ }^{45}$

Lukas berusaha membuat kisah pembaptisan dan pengakuan Yesus menjadi sedemikian menarik. Ia menggambarkan bahwa sesudah Roh Kudus tampak, langit terbuka, dan dari dalam langit itu terdengarlah suara dari surga. Sekali lagi, Lukas berusaha menghadirkan Allah dengan menggunakan tanda-tanda yang dapat diterawang oleh manusia, "langit yang terbuka dan suara dari langit." Lukas kemudian melanjutkan kisah ini dengan memberikan ending yang sangat menarik. Promulgasi Tuhan "Engkaulah Anak-Ku yang kukasihi, kepada-Mu Aku berkenan.” Promulgasi ini amat luar biasa karena identitas Anak Allah diteguhkan. Promulgasi ini serentak mengingatkan pada kata-kata Nabi Yesaya: Lihatlah, itu hamba-Ku yang Kupegang, orang pilihan-Ku yang kepadanya Aku berkenan (Yes 42:1). Lukas menampilkan Yesus sebagai Anak Allah.

Bentuk kisah yang ditampilkan oleh penginjil menggambarkan bahwa Lukas merupakan seorang "sutradara/pengisah" yang ciamik. Ia dengan handal menempatkan setiap bagian dalam cerita dengan tepat, sehingga menghasilkan sebuah kisah yang sungguh-sungguh menarik. Ia mengawali kisahnya dengan luar biasa dan mengakhirinya dengan lebih luar biasa. Ia bahkan mengisahkannya secara jelas tentang identitas Yesus dengan amat terperinci. ${ }^{46}$

Kisah mengenai Pembaptisan Yesus bukanlah sebuah kisah biasa. Kisah ini bertujuan memberikan informasi yang benar bahwa Yesus sungguh dibaptis bersama orang banyak dan pada saat itu Roh Kudus dalam rupa burung merpati sungguh turun atas Yesus. Pada saat itulah Allah Bapa menunjukkan kasih dan perkenanan kepada Yesus Anak-Nya. Kisah pembaptisan dan dipuncaki dengan pengakuan Yesus secara literer mengandung dalamnya bentuk "pengumuman." Namun bukan sebuah pengumuman yang biasa, namun sebuah pengumuman yang tegas dan lantang tentang identitas Yesus sebagai Anak Allah di hadapan banyak orang oleh Allah sendiri. ${ }^{47}$

Pengumuman tentang Anak Allah sesudah pembaptisan di satu sisi memiliki kemiripan bentuk dengan deklarasi sebelumnya yang disampaikan kepada para gembala. Pada saat itu, malaikat sang utusan Tuhan, mendekelarasikan kepada para gembala

\footnotetext{
maka itu ditafsirkan sebagai tanda perkenaan para dewa. Oleh karena itu, dengan menceritakan bahwa burung merpati hinggap di atas kepala Yesus, di sana ia menempatkan Yesus sosok yang mendapatkan perkenanan dan kasih sayang dari Allah Bapa. Leks, 126.

45 Leks, 126.

46 Leks, 22.

${ }^{47}$ Fitzmyer menggunakan kata "deklarasi" di hadapan public tentang identitas Yesus sebagai Anak Allah. Fitzmyer, The Gospel Acording To Luke, 483.
} 
demikian: "Hari ini telah lahir bagi-Mu Juruselamat, yaitu Kristus, Tuhan di Kota Daud (Luk. 2 :11)." Pola deklarasi kabar gembira ini ditandai dengan beberapa hal, yakni: ${ }^{48}$

- Seorang malaikat/utusan Tuhan menampakan diri

- Kemuliaan Tuhan yang menyelimuti kemah

- Ada keterkejutan dan ketakutan

- Malaikat meneguhkan para gembala agar tidak takut

- Malaikat mendeklarasikan "kabar gembira" kelahiran Anak Allah

- Pujian dan penyembahan yang didengungkan kepada Allah kepada Allah sesudah deklarasi

- Para gembala saling mengajak dan pergi menyaksikan kebenaran deklrasi yang disampaikan dan mengakui bahwa Allah bertindak atas hidup mereka.

- Para gembala menceritakan semua yang mereka alami kepada Maria dan Yoseph

- Maria mendengarkan, dan merenungkan kebenaran itu dalam hatinya

- Para gembala memuji dan memuliakan Tuhan atas semua yang terjadi dalam hidup mereka.

Lukas memang dengan lihai menempatkan cerita ini sehingga deklarasi yang terkandung di dalamnya memiliki kemiripan dan kaitan erat dengan kisah pembaptisan Tuhan. Lewat deklarasi tersebut, Lukas mau menegaskan satu hal penting, bahwa Yesus sungguh adalah Mesias, sang Anak Allah yang dijanjikan untuk menyelamatkan bangsa Israel. Ia adalah Juruselamat, dari Kota Daud (bdk. Luk. 2:11), dan identitas ini sungguh didengungkan ke penjuru dunia lewat mulut para gembala, orang-orang kecil yang dengan mudah menyampaikan apa yang diterimanya. ${ }^{49}$ Deklarasi ini merupakan deklarasi pertama ketika Sang Anak Allah hadir di dunia, untuk mengungkapkan bahwa Yesus sungguh Anak Allah, yang datang dari Kota Daud untuk seluruh umat manusia.

Meskipun memiliki kesamaan dari sisi tertentu, namun di sisi yang lain, deklarasi kepada para gembala dan deklarasi sesudah Pembaptisan Yesus memiliki perbedaan yang amat fundamental. Deklarasi sesudah pembaptisan Yesus merupakan deklarasi yang istimewa dan jauh lebih besar. Deklarasi tersebut terpola sebagai berikut:

- Diawali dengan pembaptisan orang banyak dan Yesus.

- Yesus yang berdoa

- Langit yang terbuka

- Roh Kudus dalam rupa burung merpati turun ke atas kepala Yesus

- Terdengar suara dari langit

- Deklarasi langsung dari Bapa bahwa Yesus adalah anakNya yang terkasih dan hanya kepada Ia berkenan.

Berdasarkan pola di atas terlihat perbedaan dengan deklarasi sebelumnya. Deklarasi sesudah Pembaptisan Yesus dibuat di hadapan orang banyak. Menurut Stefans Leks, orang banyak yang dimaksud sebenarnya satu konteks dengan yang dirujuk dalam deklarasi kepada para gembala, yakni umat. ${ }^{50}$ Namun deklarasi ini jauh lebih besar. Umat

\footnotetext{
48 Confraternity of Christian Doctrin (CCD), Holy Bible, 1095.

${ }^{49}$ Lembaga Biblika Indonesia, Tafsir Alkitab Perjanjian Baru, 120.

${ }^{50}$ Leks, Tafsir Injil Lukas, 125.
} 
yang dirujuk oleh teks ini ialah mereka yang datang dan memberi dirinya dibaptis. Mereka ini adalah kumpulan kelompok yang besar dan terkagum-kagum dengan pewartaan Yohanes Pembaptis. Tidak terhitung jumlah mereka.

Di samping itu, deklarasi tentang Yesus ditandai dengan Yesus yang berdoa, kemudian Roh Kudus menunjukkan diri dan Allah mendeklarasikan kepada orang banyak mengenai Yesus. Deklarasi ini tergolong istimewa dan tegas dalam pernyataan Allah, "Engkaulah Anak-Ku yang Kukasihi kepada-Mulah Aku berkenan." Dalam deklarasi tersebut terlihat dan terungkap dengan jelas bahwa Allahlah yang langung mendeklarasikan. Allah tidak menggunakan utusan seperti deklarasi sebelumnya. Allah memang membenarkan apa yang disampaikan oleh Malaikat, namun menggunakan otoritasNya untuk semakin memperjelas dan mempertegas identitas Yesus Sang Allah. Deklarasi itu bahkan langsung menunjuk pada Yesus yang pada saat itu dipenuhi oleh Roh Kudus. Kata Engkau menjadi bukti otentik bahwa Allah memang menunjuk pada Yesus. Di samping itu, pernyataan sesudahnya semakin mempertegas identitas itu, Yesus adalah Anak Allah yang terkasih dan hanya kepadaNya Allah berkenan. Dalam diri anakNya, Allah menyatakan perkenananNya.

Menurut Fitzmayer, deklarasi Allah di hadapan orang banyak mengenai anakNya merupakan sebuah deklarasi yang amat penting dalam Injil Lukas. Deklarasi ini menandai momen penting kehadiran Yesus di dunia, yakni pelayanan-Nya. Karena pelayanan Yesus dari Galilea dan berpuncak di Yerusalem menjadi focus Lukas dalam tulisannya. ${ }^{51}$ Lewat deklarasi Allah, terungkap bahwa Allah akan senantiasa bersama dengan Yesus dalam tugas dan pelayanan-Nya di tengah-tengah dunia karena Yesus adalah Anak Allah.

\section{Pesan Teologis}

Episode mengenai pembaptisan Yesus dan deklarasi identitasNya sebagai Anak Allah mereprenstasikan di dalamnya pesan-pesan teologis yang amat dalam, bahkan sangat Kristiani (Katolik). Tentunya pesan teologis utama yang ingin disampaikan, ialah status/identitas Yesus sebagai Anak Allah. Namun tak bisa dipungkiri bahwa ada pula pesan-pesan teologis lain yang juga ingin disampaikan dalam episode tersebut.

Pertama, Yesus merupakan Anak Allah. Lukas lewat promulgasi Allah ingin menegaskan kembali akar historis dari Yesus untuk menguatkan para pembaca yang tidak berjumpa dengan Yesus tentang kebenaran Yesus. ${ }^{52}$ Yesus sungguh Anak Allah dan ini harus menjadi kebenaran iman yang harus senantiasa diyakini dan dipegang teguh. Dengan berpegang pada kebenaran ini, maka mereka dapat bertahan di tengah pergolakan iman yang melanda mereka, yang mungkin saja meragukan keallahan Yesus, bahkan dipandang bodoh oleh orang Yunani. Memang harus diakui bahwa Lukas tidak secara langsung menyaksikan peristiwa pembaptisan Yesus dan deklarasi dirinya sebagai Anak Allah. Ia bahkan mengakui bahwa Ia bukanlah saksi mata dari tindakan dan kata-kata Yesus-Yesus: Ia berasal dari "generasi kedua" seperti halnya para pembaca yang menjadi tujuan tulisannya. ${ }^{53}$ Namun

\footnotetext{
51 Fitzmyer, The Gospel Acording To Luke, 484.

52 Lembaga Biblika Indonesia, Tafsir Alkitab Perjanjian Baru, 116.

${ }^{53}$ Lembaga Biblika Indonesia, 116.
} 
Lukas menyelediki semua kebenaran itu, sehingga ia dengan bangga dan penuh keberanian mengatakan bahwa Yesus sungguh-sungguh Anak Allah. Konsep Yesus sebagai Anak Allah ini tentunya berbeda dengan konsep hubungan ayah dan anak yang dimaknai manusia. Yesus sebagai Anak Allah menunjukkan relasi tak terpisahkan antara dirinya dengan Allah Bapa ${ }^{54}$ Ini adalah pesan yang benar dan senantiasa aktual untuk setiap pengikut Yesus. Pesan ini juga serentak menolak segala macam pandangan skeptis yang meragukan identitas Yesus sebagai Anak Allah, khususnya pada masa Yesus, para murid dan Gereja sesudahnya.

Kedua, eksistensi Trinitaris. Lukas memang tidak secara eksplisit menyebutkan bahwa tujuan tulisannya ialah untuk mempertegas eksistensi Trinitaris. Namun melalui tulisannya Lukas ingin menegaskan sebuah relasi ilahi yang di dalamnya melibatkan Bapa, Putera dan Roh Kudus. Episode pembaptisan dan deklarasi identitas Yesus menjadi bukti di mana relasi ilahi itu tampak. Allah terdiri atas Bapa, Putera dan Roh Kudus. Allah Bapa menyatakan dirinya bahwa Ia sungguh-sungguh bereksistensi lewat promulgasinya, dan Roh Kudus mengungkapkan dirinya dalam rupa burung merpati, sedangkan identitas Yesus sebagai Allah sudah terungkap lewat promulgasi Allah dan kehadiran Roh Kudus pasca pembaptisan-Nya. Dengan demikian, episode pembaptisan Yesus dan promulgasinya dapat menjadi bukti dan rujukan bahwa konsep Trinitas yang dihidupi orang Kristen itu sungguh benar. ${ }^{55}$ Kenyataan ini serentak pula mengingatkan akan adagium kuno yang dikatakan St. Hieronimus "Tidak mengenal Kitab Suci berarti tidak mengenal Allah.” Dalam dan melalui Kitab Suci kebenaran Allah terungkap secara ekplisit.

Ketiga, Yesus yang Berdoa. Episode pembaptisan dan pemakluman identitas Yesus mengungkapkan suatu kecenderungan yang ditunjukan oleh Yesus, yakni berdoa. Yesus berdoa sesudah pembaptisannya. Edward Farrel pernah mengeluarkan sebuah buku yang berjudul doa adalah sebuah keinginan (Prayer is a hunger). ${ }^{56}$ Keinginan untuk berkomunikasi dengan Tuhan. Yesus sesungguhnya bukan hanya ingin, namun sungguh merasakan betapa doa menjadi hal yang amat fundamental dalam misi-Nya. Doa adalah momen istimewa di mana Yesus berjumpa dan membangun komunikasi intim dengan Bapa dan Roh Kudus. Doa adalah sarana komunikasi antara Allah dan PuteraNya. Tindakan Yesus ini membawa sebuah pesan positif bahwa dalam dan melalui doa semua orang beriman dapat membangun komunikasi yang dekat Allah. Doa juga menjadi wujud kerendahan hati di hadapan Allah, karena dengannya kita dibersihkan dari segala kepalsuan di hadapan Allah dan mengakui bahwa Allah berkuasa atas hidup kita. Dalam konteks injil Lukas, Lukas memang menawarkan sebuah pesan positif untuk pembaca agar senantiasa berdoa kepada Tuhan.

Keempat, pembaptisan. Dalam tradisi dan ajaran Gereja Katolik, pembaptisan dipandang sebagai jalan pengangkatan sebagai Anak Allah. Pembaptisan membuat manusia memperoleh hidup baru selaku anak Allah. ${ }^{57}$ Ajaran ini sebenarnya secara biblis mendapatkan pendasaran dalam perikop Pembaptisan Yesus. Dengan kata lain,

\footnotetext{
54 JB. Banawiratma SJ (editor), Kristologi dan Allah Tritunggal (Yogyakarta: Kanisius, 1986), 26-27.

55 Oscar Lukefahr, A Catholich Guide to the Bible: Memahami dan Menafsir Kitab Suci secara Katolik (Jakarta: Obor, 2007), 171.

56 Prayer Is a Hunger, Prayer Is a Hunger (London: Great Britain, 1974).

${ }_{57}$ Niko Syukur Dister, Teologi Sistematika 2: Ekonomi Keselamatan (Yogyakarta: Kanisius, 2004), 381.
} 
Pembaptisan Yesus merupakan representasi dan puncak dari model pembaptisan Kristiani karena melaluinya orang-orang sungguh-sungguh diangkat sebagai Anak Allah. Untuk itu, memberi diri untuk dibaptis adalah sebuah jalan pertobatan untuk menjadi Anak Allah.

\section{Penutup}

Yesus adalah anak Allah. Ini merupakan sebuah pengakuan langsung dari Allah. Lewat suara dari langit, Allah memberikan pengakuan tersebut. Pengakuan Allah mengungkapkan sebuah hubungan istimewa dengan Yesus. Hubungan istimewa ini berbeda dengan hubungan biologis antara ayah dan anak. Hubungan antara Allah dan Yesus jauh melampui itu. Hubungan Allah dan Yesus mengungkapkan sebuah relasi Ilahi.

Penegasan identitas Yesus sebagai Anak Allah merupakan sebuah kebenaran yang tak terbantahkan. Lukas menyelidiki kebenaran tersebut (bdk. Luk. 1:4). Lukas adalah seorang penulis Injil yang tak begitu saja menerima pewartaan para saksi tentang Yesus, tetapi juga membuat penyelidikan historis atas pewartaan tersebut. Ia menyelidiki tradisi para saksi, bahkan berusaha menyusunnya dalam bentuk narasi teratur. ${ }^{58}$ Salah satu sumber yang turut dijadikan sumber penyelidikan Lukas ialah Markus. Sumber Markus turut mendukung kebenaran ini. Paus Benediktus XVI dalam Anjuran Apostolik Verbum Domini berkata: "Sejarah Keselamatan bukanlah mitologi, melainkan sungguh-sungguh historis, dan hal itu harus dipelajari dengan metode-metode riset historis yang serius. ${ }^{59}$ Lukas sejak dahulu sudah sampai pada kesadaran ini. Lukas menyelidiki secara historis dan membenarkan bahwa Yesus sungguh adalah Anak Allah. Kebenaran itu bahkan diberitahukan kepada Teofilus seorang pejabat tinggi kala itu. Melalui hal ini, Lukas ingin memberitahukan tentang kebenaran identitas diri Yesus sebagai Putera Allah, dan juga misi besar yang dijalankannya. ${ }^{60}$

\section{Daftar Kepustakaan}

B.J. Boland. Tafsiran Alkitab Injil Lukas. Jakarta: Gunung Mulia, 1999.

Bruce M. Metzger. A Textual Comentary On The Greek New Testament. New York: United Bible Societis, 2005.

Carl R. Holladay. A Critical Introduction To The New Testament. United States Of America: Abingdon Press, 2005.

Confraternity of Christian Doctrin (CCD). Holy Bible: The New American Bible. United States of America: Catholic Bible Publisher, 1994.

Editor: JB. Banawiratma SJ. Kristologi dan Allah Tritunggal. Yogyakarta: Kanisius, 1986. Fitzmyer. The Gospel Acording To Luke I-IX, t.t.

Komisi Kitab Suci Kepausan. Penafsiran Alkitab dalam Gereja. Yogyakarta: Kanisius, 2003.

\footnotetext{
${ }^{58}$ Leks, Tafsir Injil Lukas, 31.

59 Paus Benediktus XVI, Anjuran Apostolik Pasca Sinode Verbum Domini (Jakarta: Lembaga Biblika Indonesia, 2011), 58.

${ }^{60}$ Bdk. T. Herianto, “Kebangkitan Yesus: Analisis Naratif Injil Lukas 23:56-24:12,” Jurnal Melintas 35, no. 1 (2019): 59-60.
} 
Kurt Aland dkk. The Greek New Testament. Stutgart: Fortress Press, 1998.

"Langit." Dalam Ensiklpodi Masa Kini Jilid II. Jakarta: Yayasan Komunikasi Bina Kasi, 2011.

Lembaga Biblika Indonesia. Tafsir Alkitab Perjanjian Baru. Yogyakarta: Kanisius, 2002.

—. Tafsir Alkitab Perjanjian Lama. Yogyakarta: Kanisius, 2002.

Mathew Hendry. Comentary on The Whole Bible Volume 6. Grand Rapids: Christian Classics Ethereal Library, 1999.

Niko Syukur Dister. Teologi Sistematika 2: Ekonomi Keselamatan. Yogyakarta: Kanisius, 2004.

Oscar Lukefahr. A Catholich Guide to the Bible: Memahami dan Menafsir Kitab Suci secara Katolik. Jakarta: Obor, 2007.

Paus Benediktus XVI. Anjuran Apostolik Pasca Sinode Verbum Domini. Jakarta: Lembaga Biblika Indonesia, 2011.

Prayer Is a Hunger. Prayer Is a Hunger. London: Great Britain, 1974.

Raymond A. Brown. An Introduction To The New Testament. New York: Double Day, 1997.

Rick Brown. "The 'Son of God' Understanding the Messianic Titles of Jesus." International Journal of Frontier Missions 17, no. 1 (2000): 44.

Robert C. Tannehill. The Narrative Unity of Luke-Acts a Literary Interpretation. Philladelphia: Forter Press, 1986.

Stefan Leks. Tafsir Injil Lukas. Yogyakarta: Kanisius, 2003.

—. Tafsir Injil Markus. Yogyakarta: Kanisius, 2003.

T. Herianto. "Kebangkitan Yesus: Analisis Naratif Injil Lukas 23:56-24:12.” Jurnal Melintas 35, no. 1 (2019): 59-60.

Ungaran@Rashid. “Jesus (pbuh) as 'son of God': A Biblical Study Based on the Jewish Scriptures and the Gospel of Matthew," t.t. https://journals.iium.edu.my/alitqan/index.php/al itqan/article/view/118/50.

Yayasan Komunikasi Bina Kasih. "Doa.” Dalam Ensiklopedi Masa Kini: Jilid 1A-L. Jakarta: Yayasan Komunikasi Bina Kasi, 2011. . "Mesias.” Dalam Ensiklopedi Alkitab Masa Kini Jilid II. Jakarta: Yayasan Komunikasi Bina Kasih, 2011.

_. Tafisiran Alkitab Masa Kini (Judul Asli: The New Bible Commentary). Jakarta: Yayasan Komunikasi Bina Kasi, 1982.

—. Tafsiran Alkibat Masa Kini 3. Jakarta: BPK Gunung Mulia, 2012. . "Yesus Kristus." Dalam Ensiklpodi Masa Kini Jilid II. Jakarta: Yayasan Komunikasi Bina Kasih, 2011. 